5 Le Compte PM, Gepts W. The pathology of juvenile diabetes. In: Volk BW, Wellman KF, eds. The diabetic pancreas. New York: Plenum Press, 1977: 325-53.

(Accepted 25 fuly 1985)

Departments of Chemical Pathology and Human Metabolism and Radiology, Royal Free Hospital and School of Medicine, London

V FONSECA, MD, MRCP, research fellow

L A BERGER, FRCR, FFR, consultant radiologist

A G BECKETT, FRCP, consultant physician

P DANDONA, DPHIL, MRCP, director of metabolic unit

Correspondence to: Dr P Dandona, Department of Chemical Pathology and Human Metabolism, Royal Free Hospital, London NW3 2QG.

\section{$\alpha$ Atrial natriuretic peptide concentrations in plasma of children with congenital heart and pulmonary diseases}

Three peptides have recently been isolated from mammalian atrial myocytes, all of which have natriuretic, diuretic, and hypotensive activity. In man the smallest of these, $\alpha$ human atrial natriuretic peptide, comprises 28 amino acids.

Studies in animals suggest that the peptides are released from the atria in response to increased atrial pressure. ${ }^{2} \mathrm{~A}$ similar mechanism might play a part in controlling the release of $\alpha$ human atrial natriuretic peptide from the human heart. To test this hypothesis we measured the plasma concentrations of $\alpha$ human atrial natriuretic peptide in children with various types of congenital heart disease and bronchopulmonary dysplasia, which are known to be associated with high atrial pressure and atrial stretching.

\section{Patients, methods, and results}

Four children with bronchopulmonary dysplasia, Northway stage IV ${ }^{\prime}$ aged 17-27 months and 10 children with congenital heart diseases aged 1 month to 15 years were studied. The mean gestational age and birth weight of the children with bronchopulmonary disease was 32 weeks and $1580 \mathrm{~g}$, respectively. Among the patients with cardiac disease there were three cases of Fallot's tetralogy (one after surgical reconstruction) and one each of patent ductus arteriosus, transposition of the great arteries, ventricular septal defect, and coarctation of the aorta, tricuspid atresia, ventricular septal defect, mitral stenosis, and cardiomyopathy. All diagnoses were made on the basis of $x$ ray findings, two dimensional echocardiography, or cardiac catheterisation. None of the children had a history of any other disease known to affect water balance. The patients with bronchopulmonary dysplasia were treated with diuretics and digoxin. Four children with congenital heart disease were treated with digoxin and frusemide.

The control group consisted of 51 children ( 24 boys, 27 girls) who had been admitted to hospital aged 1 month to 16 years with endocrine disorders such as delayed puberty, retardation of growth, and obesity or who were recovering from infectious diseases or minor surgery. Children suffering from cardiac and bronchopulmonary diseases and those with disorders affecting the fluid and electrolyte balance were excluded.

Blood samples were taken for measurement of $\alpha$ human atrial natriuretic peptide concentrations from peripheral veins during routine sampling between 8 am and 11 am with patients supine. Concentrations of $\alpha$ human atrial natriuretic peptide were measured by radioimmunoassay as described above. ${ }^{3}$

The mean concentration of $\alpha$ human atrial natriuretic peptide in the control group was $27 \mathrm{fmol} / \mathrm{ml}$ (range $1-45.5 \mathrm{fmol} / \mathrm{ml}(3-136.5 \mathrm{pg} / \mathrm{ml}$ )) (figure). The mean plasma concentration in children under 1 year of age did not differ significantly from that of children older than 1 . By contrast, concentrations up to 10 times higher were found in the group of children with congenital heart or bronchopulmonary diseases. An overlap with the upper range of the concentrations of $\alpha$ human atrial natriuretic peptide in the control group was observed in the one patient who had undergone surgical reconstruction of Fallot's tetralogy.

\section{Comment}

It has recently been reported that $\alpha$ human atrial natriuretic peptide, when given as an intravenous bolus to healthy subjects, increased urinary sodium excretion and urine volume and immediately decreased blood pressure, probably owing to vasodilatation. ${ }^{45}$ This observation together with the fact that $\alpha$ human atrial natriuretic peptide is a hormone circulating in the blood implies that the cardiac atria are one site where the volume of vascular fluid is regulated. The increased concentrations of $\alpha$ human atrial natriuretic peptide in the plasma of children with cardiopulmonary disorders probably reflect the heart's attempt to counteract excessive volume or pressure by reducing plasma volume, peripheral resistance, and venous return. The concentration of circulating $\alpha$ human atrial natriuretic peptide observed in

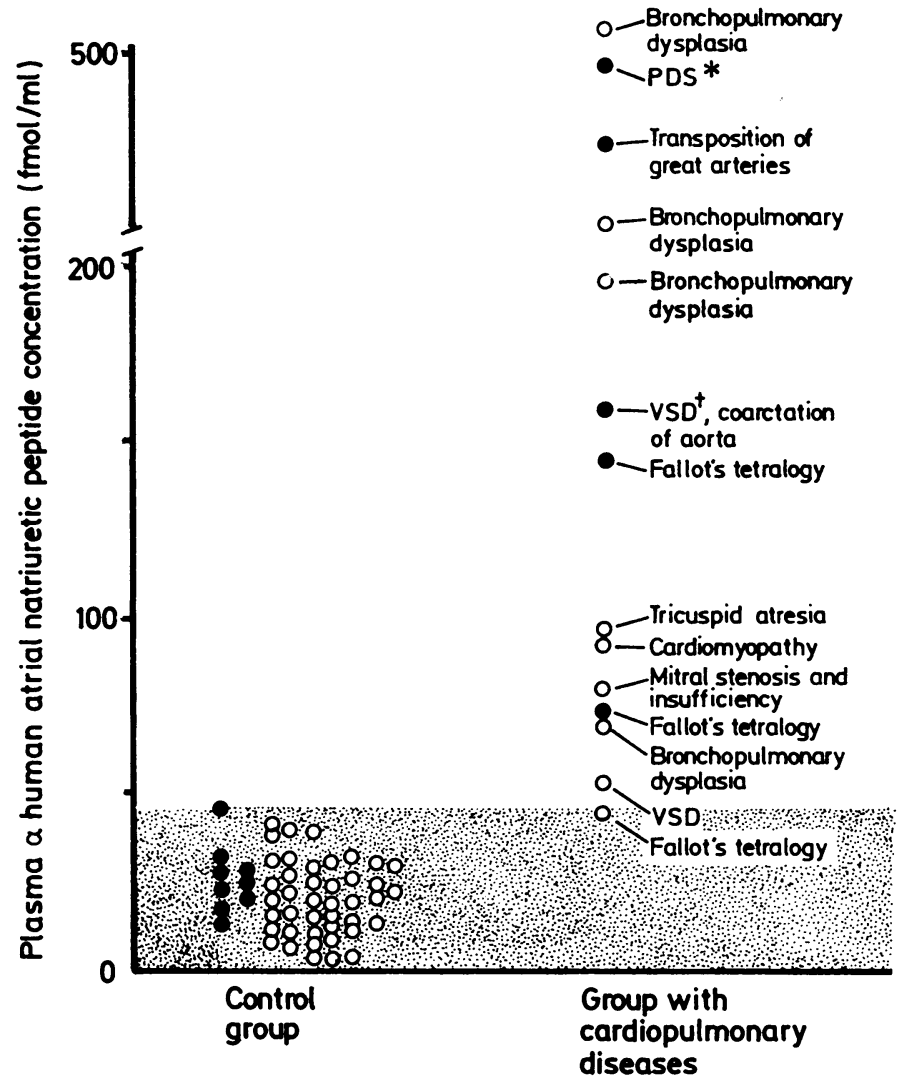

Plasma alpha human atrial natriuretic peptide concentrations in children with congenital heart diseases and bronchopulmonary dysplasia without disorders of body fluids or electrolytes compared with those in children without cardiac and pulmonary diseases. Filled circles are children aged $<1$ year.

$\star$ PDS $=$ patent ductus arteriosus.

+VSD = ventricular septal defect.

our study may be sufficiently high to elicit cardiovascular and renal effects. This is supported by Tikkanen $e t a l$, who reported that during infusions of $\alpha$ human atrial natriuretic peptide plasma concentrations above $33 \mathrm{fmol} / \mathrm{ml}$ $(100 \mathrm{pg} / \mathrm{ml})$ were associated with a slight decrease in blood pressure and a definite natriuresis and diuresis. ${ }^{5}$ The same authors showed that plasma $\alpha$ atrial human natriuretic peptide concentration was raised in patients with congestive heart failure.

This observation together with our finding of raised concentrations in children with cardiopulmonary disease are consistent with the idea that increased preload resulting in atrial stretch stimulates the release of $\alpha$ human atrial natriuretic peptide into the circulation. Moreover, the data suggest that the hormone might be valuable as a non-invasive humoral marker in the diagnosis of various cardiac and pulmonary diseases and in evaluating responses to treatment.

Needleman P, Adams SP, Cole BR, et al. Atriopeptins as cardiac hormones. Hypertensio 1985;7:469-82.

2 Lang RE, Thoelken H, Ganten D, Luft FC, Ruskoaho H, Unger T. Atrial natriuretic factor-a circulating hormone stimulated by volume loading. Nature 1985;314:264-6.

3 Rasher W, Tulassay T, Lang RE. Atrial natriuretic peptide in plasma of volume overloaded children with chronic renal failure. Lancet 1985 ;ii:303-5.

4 Richards AM, Ikram H, Yandle TG, Nicholls MG, Webster I, Espiner EA. Renal, haemodynamic and hormonal effects of human alpha atrial natriuretic peptide in healthy volunteers. Lancet 1985; i:545-9.

5 Tikkanen I, Fyhrquist F, Metsarinne K, Leidenius R. Plasma atrial natriuretic peptide in cardiac disease and during infusion in healthy volunteers. Lancet 1985;ii:66-9.

(Accepted 25 September 1985)

German Institute for High Blood Pressure Research and Department of Pharmacology, 6900 Heidelberg, West Germany

R E LANG, MD, associate professor of pharmacology

T UNGER, MD, associate professor of pharmacology

D GANTEN, MD, professor of pharmacology

Haunersches Kinderspital, University of Munich

J WEIL, MD, associate professor of paediatrics

F BIDLINGMAIER, MD, professor of paediatrics

D DOHLEMANN, MD, professor of paediatrics

Correspondence to: Dr Lang. 